\title{
Propagation and Dissemination Strategies of Transmissible Spongiform Encephalopathy Agents in Mammalian Cells
}

\author{
Stefanie-Elisabeth Heumüller ${ }^{1}$, Annika C. Hornberger ${ }^{1}$, Alina S. Hebestreit ${ }^{1} \mathbb{D}$, André Hossinger ${ }^{1}$ \\ and Ina M. Vorberg $1,2, *$ (D)
}

1 Laboratory of Prion Cell Biology, German Center for Neurodegenerative Diseases Bonn (DZNE e.V.), Venusberg-Campus 1/99, 53127 Bonn, Germany; stefanie-elisabeth.heumueller@dzne.de (S.-E.H.); annika.hornberger@dzne.de (A.C.H.); alina.hebestreit@dzne.de (A.S.H.); andre.hossinger@dzne.de (A.H.)

2 German Center for Neurodegenerative Diseases (DZNE), Rheinische Friedrich-Wilhelms-Universität Bonn, Siegmund-Freud-Str. 25, 53127 Bonn, Germany

* Correspondence: ina.vorberg@dzne.de

\section{check for}

updates

Citation: Heumüller, S.-E.;

Hornberger, A.C.; Hebestreit, A.S.;

Hossinger, A.; Vorberg, I.M.

Propagation and Dissemination

Strategies of Transmissible

Spongiform Encephalopathy Agents

in Mammalian Cells. Int. J. Mol. Sci.

2022, 23, 2909. https://doi.org/

$10.3390 /$ ijms 23062909

Academic Editor: Anton Nizhnikov and Yury O. Chernoff

Received: 31 January 2022

Accepted: 1 March 2022

Published: 8 March 2022

Publisher's Note: MDPI stays neutral with regard to jurisdictional claims in published maps and institutional affiliations.

Copyright: (c) 2022 by the authors. Licensee MDPI, Basel, Switzerland. This article is an open access article distributed under the terms and conditions of the Creative Commons Attribution (CC BY) license (https:/ / creativecommons.org/licenses/by/ $4.0 /)$.

\begin{abstract}
Transmissible spongiform encephalopathies or prion disorders are fatal infectious diseases that cause characteristic spongiform degeneration in the central nervous system. The causative agent, the so-called prion, is an unconventional infectious agent that propagates by converting the host-encoded cellular prion protein PrP into ordered protein aggregates with infectious properties. Prions are devoid of coding nucleic acid and thus rely on the host cell machinery for propagation. While it is now established that, in addition to $\operatorname{PrP}$, other cellular factors or processes determine the susceptibility of cell lines to prion infection, exact factors and cellular processes remain broadly obscure. Still, cellular models have uncovered important aspects of prion propagation and revealed intercellular dissemination strategies shared with other intracellular pathogens. Here, we summarize what we learned about the processes of prion invasion, intracellular replication and subsequent dissemination from ex vivo cell models.
\end{abstract}

Keywords: transmissible spongiform encephalopathies; prion; PrP; amyloid; virus

\section{Introduction}

Transmissible spongiform encephalopathies or prion diseases are neurodegenerative diseases that are characterized by the deposition of host-encoded prion proteins as highly stable, beta-sheet rich polymeric aggregates in the central nervous system [1]. Prion diseases affect humans and other mammals and can be of sporadic, genetic or infectious origin. In animals, natural infection usually occurs through contact and/or ingestions of contaminated biological materials [2]. In humans, prion diseases are mainly sporadic, with some genetic cases. Both iatrogenic and zoonotic transmissions have been reported [1] Prions form by aberrant folding of cellular prion protein PrP into highly ordered protein aggregates with self-templating activities. Once formed, prions convert cellular $\operatorname{PrP}\left(\operatorname{PrP}^{\mathrm{C}}\right)$ into its aggregated isoform $\mathrm{PrP}^{\mathrm{Sc}}$, thereby indefinitely propagating $\mathrm{PrP}$ misfolding [3-5]. A so-far unknown process results in fragmentation of formed $\mathrm{PrP}^{\mathrm{SC}}$ aggregates, leading to the generation of smaller seeds that can be transmitted to other cells [6]. A peculiar feature of prions is their existence as strains. When introduced into the same mammalian species, prions can cause disease phenotypes that differ in incubation times, clinical presentation, host organ and cell tropism and neuropathological characteristics such as $\mathrm{PrP}^{\mathrm{Sc}}$ deposition patterns and spongiform degeneration [7]. Once established in the new host, prion strains are quite stable, causing specific clinical phenotypes and neuropathological changes upon subsequent passage. As prions do not contain a nucleic acid genome, strain information is likely enciphered within the three-dimensional fold of the $\operatorname{PrP}^{\mathrm{Sc}}$ polymer [8]. Indeed, biophysical and biochemical characterization of $\mathrm{PrPSc}^{\mathrm{Sc}}$ molecules associated with different prion strains argue that prion strain information is encrypted in conformational variants 
of PrP polymers [9]. Cell-free experiments further argue that cofactors both promote or restrict formation of certain prion conformations that are associated with different disease phenotypes [10-12].

Prions are cell-associated pathogens that transmit to neighboring cells by different routes. These include the potential release of naked $\mathrm{PrP}^{\mathrm{Sc}}$ molecules [13], transfer to neighboring cells by direct cell contact $[14,15]$ or secretion of $\mathrm{PrPSc}^{\mathrm{Sc}}$ in association with extracellular vesicles by infected cells [16]. However, how exactly is $\mathrm{PrP}^{\mathrm{Sc}}$ taken up by recipient cells and how do PrP-derived prion strains differ in their cellular propagation and dissemination routes? Here we discuss what we know from cellular models on how PrP-derived prions enter and replicate within their target cells.

\section{Cell Biology of Cellular PrP}

The cellular prion protein $\operatorname{PrP}^{\mathrm{C}}$ serves as a substrate for $\operatorname{PrP}^{\mathrm{Sc}}$ formation and is essential for prion propagation. It is anchored to the cell membrane by a glycosyl-phosphatidylinositol moiety (GPI). $\mathrm{PrP}^{\mathrm{C}}$ is predominately expressed in the central nervous system and, to a lesser extent, in the lymphoreticular system, the female genital tract, intestine, colon and thyroid (reviewed in [17]). Several functions for $\operatorname{PrP}^{\mathrm{C}}$ have been proposed, including neuronal activity and viability, cell adhesion, cell cycle and immune regulation (reviewed in [18]). Interestingly, $\mathrm{PrP}^{\mathrm{C}}$ also plays a role in cancer development by regulating cancer stem cell properties and chemoresistance [19]. Recent analyses suggest that $\operatorname{PrP}^{\mathrm{C}}$ functions through interacting and mediating the posttranslational modification of NCAM1, thereby controlling epithelial-to-mesenchymal transition and related plasticity programs [20].

Following synthesis and glycosylation in the endoplasmic reticulum and Golgi, mature $\mathrm{PrP}^{\mathrm{C}}$ is present on the cell surface. $\mathrm{PrP}^{\mathrm{C}}$ is mainly found in rafts, membrane microdomains enriched in phospholipids and cholesterol $[21,22]$. Some $\mathrm{PrP}^{\mathrm{C}}$ molecules undergo proteolytic cleavage or membrane shedding (reviewed in [23]). $\operatorname{PrP}^{\mathrm{C}}$ is also secreted from cells in association with extracellular vesicles, small membrane-bound delivery devices for intercellular communication [24]. $\mathrm{PrP}^{\mathrm{C}}$ can be internalized from the cell surface by different routes in different cell types [24-29]. Following internalization by clathrin-, caveolin- or raft-mediated endocytosis, $\operatorname{PrP}^{\mathrm{C}}$ is transported through early endosomes and either recycled back to the cell surface [27] or trafficked to late endosomes and subsequently to the lysosome for clearance $[30,31]$. The route of $\mathrm{PrP}^{\mathrm{C}}$ uptake is at least partially determined by the sorting receptor VSP10P sortilin, which directly interacts with $\mathrm{PrPC}^{\mathrm{C}}$, moves it out of rafts and mediates its transport to the lysosome [30]. Another factor identified is muskelin which directs $\mathrm{PrP}^{\mathrm{C}}$ towards the lysosome [32]. Following transport to the lysosome, $\mathrm{PrP}^{\mathrm{C}}$ is degraded with a half-life of approximately 5 to $24 \mathrm{~h}$. Differences in half-lives likely depend on the amount of $\operatorname{PrP}^{\mathrm{C}}$ expressed by the cells $[33,34]$.

\section{Cellular Models for Prion Propagation}

The cell biology of prion replication is only incompletely understood. In vivo, neurons and astrocytes represent the major targets for prion replication, with certain cells of the lymphoreticular system also acting as hosts [35]. In vitro, however, only few cell lines of diverse origins are permissive to prion replication (Table 1) [16]. These include brain-derived cell lines of neuronal, astroglial, microglial or Schwann cell origin, but also fibroblasts, epithelial or muscle cells (reviewed in [36]). Not all cell lines of these origins can be infected, so that prion susceptibility must be detected empirically (reviewed in [16]). Once infection is established, prions persistently replicate in susceptible cell lines without overt cytotoxic effects. It is unclear, what-other than $\mathrm{PrP}$-controls prion infection in vitro. The relative expression level of $\operatorname{PrP}^{\mathrm{C}}$ does not appear to be the limiting factor for successful infection [37-39]. Susceptibility is both dependent on the cell line and prion strain, with some cell lines capable of propagating one prion strain but being resistant to another one (reviewed in [36]). Importantly, even in prion-permissive cell lines, the percentage of cells that become persistently infected can substantially differ $[38,40]$. Infection rates can be so low that $\mathrm{PrP}^{\mathrm{Sc}}$ is undetectable by Western blot, despite prion infectivity being confirmed by 
mouse bioassay [40]. In these cases, selection of cell clones with increased susceptibility helps to drastically increase attack rates $[28,38,41]$.

Table 1. Cell lines susceptible to prions.

\begin{tabular}{|c|c|c|c|c|c|}
\hline $\begin{array}{l}\text { Species } \\
\text { Inoculum }\end{array}$ & TSE & Strain & Prion Susceptible Cell Line & Expressed PrP & References \\
\hline \multirow{7}{*}{ Sheep } & \multirow{7}{*}{ Scrapie } & Natural Scrapie & $\begin{array}{l}\text { RK13, hTERT microglia, } \\
\text { MovS6/ MovS2 cells }\end{array}$ & Ovine & [42-44] \\
\hline & & & $\begin{array}{c}\text { Primary neurons: cerebellar } \\
\text { granular, iPSC- } \\
\text { derived astrocytes }\end{array}$ & Ovine & [45] \\
\hline & & $127 \mathrm{~S}$ & RK13, MovS6/ MovS2 cells & Ovine & {$[13,41]$} \\
\hline & & PG127 & Rov cells & Ovine & [46] \\
\hline & & LA404 & Rov cells & Ovine & {$[46]$} \\
\hline & & Kanagawa Scrapie & GT1 & Murine & [47] \\
\hline & & Obihiro Scrapie & MG20 & Murine & [48] \\
\hline \multirow{5}{*}{ Elk/Deer } & \multirow{5}{*}{$\begin{array}{l}\text { Cervid chronic } \\
\text { wasting disease } \\
\text { (CWD) }\end{array}$} & & CAD5 & Cervid & [49] \\
\hline & & viule Deer crvo & MEF & bank Vole/cervid & [49] \\
\hline & & (IVD-CVVD) & MDB & Mule Deer & [50] \\
\hline & & $\begin{array}{l}\text { White-Tailed Deer } \\
\text { CWD (WT-CWD) }\end{array}$ & $\begin{array}{l}\text { CAD5 } \\
\text { MEF }\end{array}$ & $\begin{array}{c}\text { Cervid } \\
\text { Bank Vole/cervid }\end{array}$ & [49] \\
\hline & & Elk CWD & RK13 & Elk & [51] \\
\hline Cattle & $\begin{array}{l}\text { Bovine } \\
\text { spongiform en- } \\
\text { cephalopathy } \\
\text { (BSE) }\end{array}$ & BSE & MG20 & Murine & [48] \\
\hline \multirow{3}{*}{ Human } & \multirow{3}{*}{$\begin{array}{l}\text { Creutzfeldt- } \\
\text { Jakob disease } \\
\text { (CJD) }\end{array}$} & Sporadic CJD & $\begin{array}{c}\text { Primary neurons: cerebellar } \\
\text { granular, iPSC- } \\
\text { derived astrocytes }\end{array}$ & Human & {$[52,53]$} \\
\hline & & Variant CJD & $\begin{array}{c}\text { Primary neurons: cerebellar } \\
\text { granular, iPSC- } \\
\text { derived astrocytes }\end{array}$ & Human & {$[52,53]$} \\
\hline & & Iatrogenic (iCJD) & $\begin{array}{l}\text { Primary neurons: } \\
\text { cerebellar granular }\end{array}$ & Human & [52] \\
\hline \multirow{7}{*}{$\begin{array}{l}\text { Mouse- } \\
\text { adapted }\end{array}$} & \multirow{7}{*}{ Scrapie } & \multirow[t]{2}{*}{ Ch./RML } & $\begin{array}{l}\text { N2a (and subclones), SMB, GT1, } \\
\text { CAD5, SN56, 1C11, MG20, } \\
\text { C8D1A, MSC-80, L929, RK13 }\end{array}$ & Murine & $\begin{array}{c}{[38,42,48,54-} \\
62]\end{array}$ \\
\hline & & & $\begin{array}{c}\text { Primary neurons: } \\
\text { cortical, hippocampal }\end{array}$ & Murine & {$[56,63,64]$} \\
\hline & & 79 A & $\begin{array}{l}\text { N2a PK1 subclone, SMB, } \\
\text { CAD5, L929 }\end{array}$ & Murine & {$[39,40,48,65]$} \\
\hline & & \multirow{4}{*}{$139 \mathrm{~A}$} & $\begin{array}{c}\text { N2a (and subclone), SMB, GT1, } \\
\text { CAD5, CRBL, L929 }\end{array}$ & Murine & $\begin{array}{c}{[39,40,48,65} \\
66]\end{array}$ \\
\hline & & & PC12 & Rat & {$[67]$} \\
\hline & & & $\begin{array}{c}\text { Primary neurons: cortical, } \\
\text { striatal }\end{array}$ & Murine & {$[68]$} \\
\hline & & & $\begin{array}{l}\text { Primary neurons: cerebellar } \\
\text { granular, astrocytes }\end{array}$ & Murine/ovine & {$[41,69]$} \\
\hline
\end{tabular}


Table 1. Cont.

\begin{tabular}{|c|c|c|c|c|c|}
\hline $\begin{array}{l}\text { Species } \\
\text { Inoculum }\end{array}$ & TSE & Strain & Prion Susceptible Cell Line & Expressed PrP & References \\
\hline & & $22 \mathrm{~L}$ & $\begin{array}{c}\text { N2a (and subclones), GT1, } \\
\text { CAD5, SN56, 1C11, HpL3-4, } \\
\text { CF10, C8D1A, L929, } \\
\text { NIH/3T3, RK13 } \\
\text { Primary neurons: cerebellar } \\
\text { granular, cortical, } \\
\text { striatal, hippocampal }\end{array}$ & $\begin{array}{l}\text { Murine } \\
\text { Murine }\end{array}$ & $\begin{array}{c}{[39,40,57,62,} \\
70-73] \\
{[56,63,74]}\end{array}$ \\
\hline & & \multirow{3}{*}{ ME 7} & $\begin{array}{c}\text { N2a subclones, CAD5, SN56, } \\
\text { MG20, L929 }\end{array}$ & Murine & {$[39,48,61,75]$} \\
\hline & & & \multirow{2}{*}{$\begin{array}{l}\text { Primary neurons: } \\
\text { cerebellar granular } \\
\text { PC12 }\end{array}$} & Murine & [76] \\
\hline & & & & Rat & [67] \\
\hline & & $22 \mathrm{~F}$ & SMB & Mouse & {$[54]$} \\
\hline & BSE & $301 \mathrm{C}$ & CAD5 & Murine & [55] \\
\hline & \multirow{3}{*}{ CJD } & M1000 & RK13 & Murine & {$[60,77]$} \\
\hline & & SY & GT1 & Murine & [78] \\
\hline & & FU & N2a, GT1 & Murine & [79] \\
\hline & \multirow[t]{2}{*}{ GSS } & \multirow[t]{2}{*}{ Fukuoka 1 (Fu-1) } & \multirow{2}{*}{$\begin{array}{c}\text { GT1, 1C11, RK13 } \\
\text { Primary neurons: cerebellar } \\
\text { granular }\end{array}$} & Murine & {$[57,72]$} \\
\hline & & & & Murine & {$[68,76]$} \\
\hline $\begin{array}{c}\text { Bank } \\
\text { vole-adapted }\end{array}$ & BSE & $\begin{array}{l}\text { Bank vole-adapted } \\
\text { BSE }\end{array}$ & RK13 & Bank vole & [60] \\
\hline \multirow[t]{2}{*}{$\begin{array}{l}\text { Hamster- } \\
\text { adapted }\end{array}$} & $\begin{array}{c}\text { Transm. mink } \\
\text { encephalopa- } \\
\text { thy } \\
\text { (TME) }\end{array}$ & Hyper (HY) & CAD5 & Hamster & [80] \\
\hline & Scrapie & $\begin{array}{l}263 \mathrm{~K} \\
139 \mathrm{H}\end{array}$ & $\begin{array}{l}\text { CAD5 } \\
\text { CAD5 }\end{array}$ & $\begin{array}{l}\text { Hamster } \\
\text { Hamster }\end{array}$ & $\begin{array}{l}{[80]} \\
{[80]}\end{array}$ \\
\hline
\end{tabular}

Abbreviations: CAD5—-mouse catecholaminergic neurons; CF10—mouse neuronal cells; CRBL-mouse cerebellum cells; C8D1A—mouse astrocytic cells; GT-1—mouse hypothalamic neurons; HpL3-4—mouse hippocampal cells; hTERT—immortalized ovine microglia; L929-mouse fibroblasts; MDB—mule deer meningeal fibroblasts, MEF mouse embryonic fibroblasts; MG20 mouse microglia cells; MovS6/MovS2 mouse Schwann cells; MSC80 mouse Schwann cells; N2a-mouse neuroblastoma cells; PC12 - rat pheochromocytoma; NIH/3T3 mouse fibroblasts; Rov—rabbit kidney epithelial cells expressing ovine PrP; RK13—rabbit kidney epithelial; SMB — mouse brain cells, SN56-mouse septal neurons; 1C11-mouse embryonal carcinoma cells (neuronal stem cells).

Surprisingly, even isogenic clones derived from the same cell line can be highly susceptible to some prion strains, but refractory to others derived from the same host $[39,46,47]$. This characteristic of cell clones has been successfully used to discriminate prion strains in vitro [55]. One reason for the differences in prion susceptibility is the genomic instability of cell lines, resulting in clonal cell populations with slightly differing genetic make-ups [74]. Cell clones have also helped to uncover some factors governing susceptibility to prion infection [74,81-83]. For example, analysis of N2a cell clones uncovered that a network of genes involved in extracellular matrix homeostasis, including genes for sulfation of glycosaminoglycans, was related to increased susceptibility to certain prions [82]. Genes associated with cell proliferation, protein degradation and heparin binding were detected to influence permissiveness of immortalized sheep microglia to ovine prions [81].

The cell biology of prion replication has been mainly studied in permanent cell lines with few prion strains that can efficiently propagate in vitro. First demonstration of $\mathrm{PrP}^{\mathrm{Sc}}$ formation upon prion infection was achieved in mouse neuroblastoma cell line N2a exposed to RML/Chandler prions [62]. Subsequently, infections were also performed with 22L, as this strain resulted in high infection rates and could be propagated reliably in cell 
culture [38,39]. More recently, neuronal and astroglial cultures from wildtype or transgenic mice have also been successfully used for infection studies $[41,68,84,85]$. Because of the lack of species-specific cell culture systems, researchers focused on ectopic expression of species-specific $\operatorname{PrP}^{\mathrm{C}}$ in heterologous cell cultures. The rabbit kidney epithelial cell line RK13 proved to be an outstanding cellular model for propagation of several prion strains from diverse species [60]. RK13 cells exhibit only limited to no expression of endogenous PrP. Engineered to overexpress murine [60], sheep [46], elk [70] or bank vole PrP [13], these cells became permissive to infection with prion strains propagated in the respective species. Surprisingly, however, infection of RK13 cells overexpressing human PrP with humanderived prions proved ineffective [86]. Similar heterologous systems were established to propagate bovine spongiform encephalopathy prions [87]. What we learn from these heterologous cell models is: (1) that cellular factors required for prion propagation are not necessarily species specific and (2) that also in heterologous systems strain-specific factors control establishment of persistent infections.

\section{The Infection Process-The Uptake of Prions}

Infection of cells with prions is mostly performed with crude brain homogenate, as this proved to be more efficient than purified $\mathrm{PrP}^{\mathrm{Sc}}$ [88]. One possible reason for the inefficient infection with purified $\mathrm{PrP}^{\mathrm{Sc}}$ fibrils is that these tend to stick to the cellular membrane for a long time, thereby delaying uptake $[56,89,90]$. Indeed, one bottleneck for efficient infection appears to be protein aggregate size, as sonication used to break up amyloid fibrils derived from different proteins promotes cellular uptake [71]. Further, mixing of brain homogenate with cationic lipids increases subsequent infection of permanent and primary cells, likely due to better uptake of infectious inoculum due to positive charge [91,92].

So far, no exclusive receptor has been identified that is required for prion uptake. Several lines of evidence suggest that glycosaminoglycans (GAGs) such as heparan sulfates present on the cell surface and in the endocytic system are required for prion propagation (Figure 1) [93]. However, chemical inhibition of GAG biosynthesis has divergent effects on prion uptake, possibly due to different prion strains used for infection or differences in the purification grade of the inoculum [94]. Other potential receptors include the $37 \mathrm{kDa} / 67 \mathrm{kDa}$ laminin receptor (LRP/LR) [95] and low-density lipoprotein receptorrelated protein 1 (Lrp1) [90]. Uptake is not sufficient for infection and also cells lacking $\operatorname{PrP}^{\mathrm{C}}$ efficiently internalize external $\mathrm{PrP}^{\mathrm{Sc}}[56,89,90,96]$. Genetic and chemical manipulation of endocytosis pathways demonstrated that prions are preferentially taken up by clathrinand caveolin-independent routes or are able to bypass these routes when blocked [28]. Impairment of one internalization pathway can increase alternative pathways, such as macropinocytosis, that allow efficient $\mathrm{PrP}^{\mathrm{Sc}}$ internalization [28]. Once internalized, some purified $\mathrm{PrP} \mathrm{Pc}^{\mathrm{Sc}}$ enters the endocytic-recycling pathway that transports cargo and receptors back to the cell surface, but the majority is trafficked to the endo-lysosomal pathway [97]. Studies with purified $\mathrm{PrP}^{\mathrm{Sc}}$ as inoculum suggest that re-direction of the inoculum and/or newly generated $\mathrm{PrP}^{\mathrm{Sc}}$ to the endocytic-recycling pathway is important for efficient accumulation of newly formed $\mathrm{PrP}^{\mathrm{Sc}}$ [97]. Impairment of the route of initial internalization influences the outcome of persistent infections in a strain-dependent manner [28]. In L929 mouse fibroblast cells, impairment of clathrin-mediated endocytosis results in decreased infection with mouse-adapted prion strain RML, while it benefits productive infection with strain 22L. While the reason for the different fates of prions is unknown, such manipulations may shunt invading prions to different endo-lysosomal compartments that may or may not contain factors or conditions that affect $\mathrm{PrP}^{\mathrm{Sc}}$ formation or clearance in a straindependent manner. 


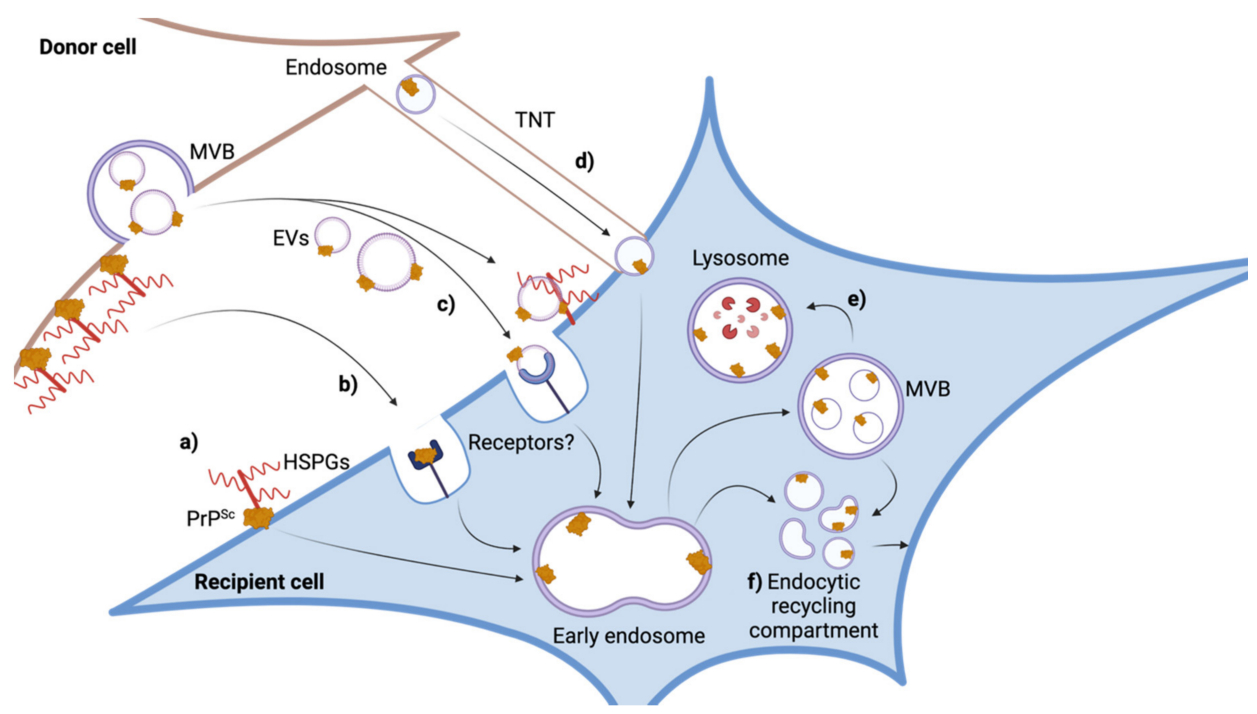

Figure 1. Prion infection mechanisms. Dissemination of $\mathrm{PrP}^{\mathrm{Sc}}$ relies on different routes. $\mathrm{PrP}^{\mathrm{Sc}}$ can be transmitted from a donor (brown) to a recipient (blue) cell. Most studies on prion uptake and infection have been performed with purified $\mathrm{PrP}^{\mathrm{Sc}}$ or with crude brain homogenate containing prions. If $\mathrm{PrP}^{\mathrm{Sc}}$ is "freely" released into the extracellular space is unknown. (a) Receptors for exogenously added $\mathrm{PrP}^{\mathrm{Sc}}$ include heparan sulfate proteoglycans (HSPGs), Lrp1 or the $37 \mathrm{kDa} / 67 \mathrm{kDa}$ laminin receptor (LRP/LR). (b) "Free" $\mathrm{PrPSc}^{\mathrm{Sc}}$ can be internalized by different endocytosis routes or macropinocytosis. (c) In cellular systems, $\mathrm{PrP}^{\mathrm{Sc}}$ can be released from donor cells via microvesicles shedding from the cell surface or in association with smaller extracellular vesicles (EVs) derived from multivesicular bodies (MVBs) that fuse with the cell membrane. EVs can be taken up by recipient cells by different pathways. Few EV ligands that mediate binding to target cells have been identified. Viral ligands present on $\mathrm{PrP}^{\mathrm{Sc}}$-containing EV can bind to recipient cells and facilitate subsequent infection. (d) $\mathrm{PrPSc}^{\mathrm{Sc}}$ can also transmit to recipient cells within endosomal vesicles through tunneling nanotubes (TNTs). (e) Within target cells, the majority of internalized $\mathrm{PrP}^{\mathrm{Sc}}$ is directed to the lysosome for degradation. (f) Newly formed $\mathrm{PrP}^{\mathrm{Sc}}$ can be found on the cell surface, within the endocytic recycling pathway and the endo-lysosomal pathway. Productive infection requires $\operatorname{PrP}^{\mathrm{C}}$ expression but is determined by additional cellular factors and the prion strain. Created with BioRender.

\section{Detection of Productive Infections}

Acute $\operatorname{PrPSc}$ formation following prion exposure can be a fast process, with de novo $\mathrm{PrPS}^{\mathrm{Sc}}$ formation being detectable within minutes to hours $[46,81,82]$. Still, initial $\operatorname{PrPSc}$ formation can also occur with prion strains incapable of establishing persistent infections, arguing that processes or factors downstream of cellular uptake regulate productive $\mathrm{PrPSc}^{\mathrm{Sc}}$ formation [98]. Persistent infection requires that $\mathrm{PrP}^{\mathrm{Sc}}$ formation exceeds clearance and cell division, two processes that reduce the net amount of $\mathrm{PrP}^{\mathrm{Sc}}$ [34,99]. Mitotically active cells are thus ideally suited to monitor ongoing $\mathrm{PrPSc}^{\mathrm{Sc}}$ formation rather than aggregate persistence [100]. However, cell division potentially also prevents propagation of certain prion strains in cellula [53]. This might be especially true for human prions, which so far only propagate in slow proliferating stem-cell derived astrocytes [53] or mixed astroglial cultures derived from transgenic mice [91]. It is possible that kinetics of human prion formation in vitro is slower than cell doubling, so that persistent infection cannot be established.

A problem with determining the time point of established prion infection is that exposures are usually performed with excess $\mathrm{PrPSc}^{\mathrm{Sc}}$-containing inoculum (usually $1 \%$ w/v brain homogenate). Consequently, in mitotically active prion cell models, productive prion infection is monitored several cell passages post infection to dilute remaining inoculum. Weak $\mathrm{PrP}^{\mathrm{Sc}}$ signals by Western blot are usually apparent at early passage and increase in subsequent passages [46]. The expression of antibody-epitope tagged $\operatorname{PrP}^{C}$ helped to discriminate inoculum from newly formed $\mathrm{PrP}^{\mathrm{Sc}}$ and demonstrated the formation of 
$\mathrm{PrP}^{\mathrm{Sc}}$ in two different cell lines within 2-3 passages post exposure to $22 \mathrm{~L}$ prions $[38,101]$. Further, a combination of fluorescently labelled $\mathrm{PrP}^{\mathrm{Sc}}$ for infection and antibodies that primarily bind to $\mathrm{PrP}^{\mathrm{Sc}}$ rather than $\mathrm{PrPC}^{\mathrm{C}}$ demonstrated increased accumulation of total $\mathrm{PrP}^{\mathrm{Sc}} 72 \mathrm{~h}$ post exposure [97]. Thus, productive prion infections in permanent cell lines can be monitored approximately within 6-9 days post infection.

Detection of productive prion infection in primary cells requires extensive rinsing of cells, as inoculum cannot be diluted by cell splitting. A gradual increase in $\operatorname{PrP}^{\mathrm{Sc}}$ signal following prion exposure is indicative of successful infection. Primary neurons and astrocytes exposed to 22L prions showed increased $\mathrm{PrPSc}^{\mathrm{Sc}}$ levels 14-21 days p.i. [96,102]. Similar results were obtained with primary cerebellar granule neurons (CGN) from transgenic mice expressing human $\operatorname{PrP}^{\mathrm{C}}$ exposed to different human Creutzfeldt-Jakob disease (CJD) strains [52]. De novo production of $\mathrm{PrP}^{\mathrm{Sc}}$ was first observed in stem-cell derived human astrocytes as soon as 3-8 days post exposure to vCJD or sCJD brain homogenate [53]. In another study, however, mixed glial cultures from transgenic mice expressing human $\mathrm{PrP}^{\mathrm{C}}$ were exposed to human $\mathrm{vCJD}$ or SCJD prions, newly-formed $\mathrm{PrP}^{\mathrm{Sc}}$ was first detected approximately 120 days post infection [91]. Thus, cell system and/or prion strain strongly influence kinetics of the establishment of prion infections.

\section{The Site of $\operatorname{PrP}^{\mathrm{Sc}}$ Formation in Persistently Infected Cells}

The exact cellular location of PrP conversion is still ill-defined and might differ depending on the cell type or the prion strain. It can also change from acute to persistent infection [28]. Early experiments with persistently infected cells demonstrated that $\mathrm{PrP}^{\mathrm{Sc}}$ is derived from $\mathrm{PrP}^{\mathrm{C}}$ that is first present on the cell surface $[103,104]$. $\mathrm{PrP}^{\mathrm{Sc}}$ 's self-templating property in mammalian cells is related to its membrane tether [105]. Anchorless $\mathrm{PrP}^{\mathrm{C}}$ is unable to maintain prion propagation in cell culture [106]. Exchange of the GPI-anchor for other membrane tethers prevents conversion of $\mathrm{PrP}^{\mathrm{C}}$ to its pathologic isoform [106,107]. In persistently infected cells, $\mathrm{PrP}^{\mathrm{Sc}}$ formation occurs either directly on the cell surface or along the endocytic pathway following internalization. Interestingly, worm-like structures of $\mathrm{PrP}^{\mathrm{Sc}}$ are detectable on the cell surface of infected cells [108]. $\operatorname{PrP}^{\mathrm{Sc}}$ has also been found in basically all compartments of the endo-lysosomal system (for a review, see [109]). Recycling endosomes and/or the multivesicular bodies have been proposed as major sites of conversion [110-112]. Eventually, in cellular models, $\mathrm{PrP}^{\mathrm{Sc}}$ is trafficked to the lysosomes for clearance [104,113]. In N2a cells, $\mathrm{PrP}^{\mathrm{Sc}}$ has a half-life of less than 2 days [34]. Infection experiments with mixed cultures of cerebellar granule cells and astrocytes confirmed the presence of $\mathrm{PrP}^{\mathrm{Sc}}$ in the endosomal recycling compartment and lysosomes [96].

For multiplication of prions, growing prion aggregates must somehow be fragmented to produce seeds that can be transmitted to daughter cells or bystanders. PrP's unique location on the cell surface and within endo-lysosomal compartments could enable interaction with cellular factors mediating efficient fragmentation and thereby replication of protein aggregates [6,105]. While such factors have so far not been identified in mammalian cells, it is important to note that the disaggregase Hsp104, which turns protein aggregates in lower eukaryotes into self-templating entities, lacks a homologue in mammalian cells [114]. Any potential fragmentation process must thus be accomplished by other cellular processes.

\section{Intercellular Dissemination of Prions}

Prion strains exhibit selected brain region- and cell-tropism, with some strains preferentially targeting neurons, while others also accumulate in astrocytes [115]. The exact mechanisms of prion spreading in vivo remain elusive and most of our understanding of such processes stems from observations made with cellular models. Interestingly, prion maintenance in cell culture is mainly due to segregation of prions to both daughter cells during cell division [99]. $\mathrm{PrP}^{\mathrm{Sc}}$ signal intensities on Western blots and percentages of infected cells can increase over multiple cell divisions, demonstrating that prions also horizontally transmit to naïve bystander cells [101]. 
$\mathrm{PrP}^{\mathrm{Sc}}$ can be directly transmitted to acceptor cell membranes in close proximity to the infected cell [14]. The association with the cell membrane facilitates spreading of $\mathrm{PrP}^{\mathrm{Sc}}$ from cell to cell by tunneling nanotubes, thin, transient actin-rich tubes connecting cells for transfer of organelles and endocytic vesicles (Figure 2) [116]. Experiments with 22Linfected primary astrocytes demonstrated that efficient intercellular transfer of $\mathrm{PrP}^{\mathrm{Sc}}$ to recipient $\mathrm{CAD}$ cells was predominately due to close cell contact, suggesting that tunneling nanotubes or other cellular contacts facilitate prion transfer [96]. Direct evidence for this intercellular transfer came from co-culture experiments with a cell line persistently propagating mouse-adapted prion strain 139A [15]. $\mathrm{PrPSc}^{\mathrm{Sc}}$ molecules could theoretically traverse intercellular bridges such as tunneling nanotubes to uninfected cells by propagating along the surface of the tubular conduits [108]. However, $\mathrm{PrP}^{\mathrm{Sc}}$ also colocalizes with endocytic compartments in tunneling nanotubes, suggesting that prions hijack these vesicles for intercellular transmission [117].

a
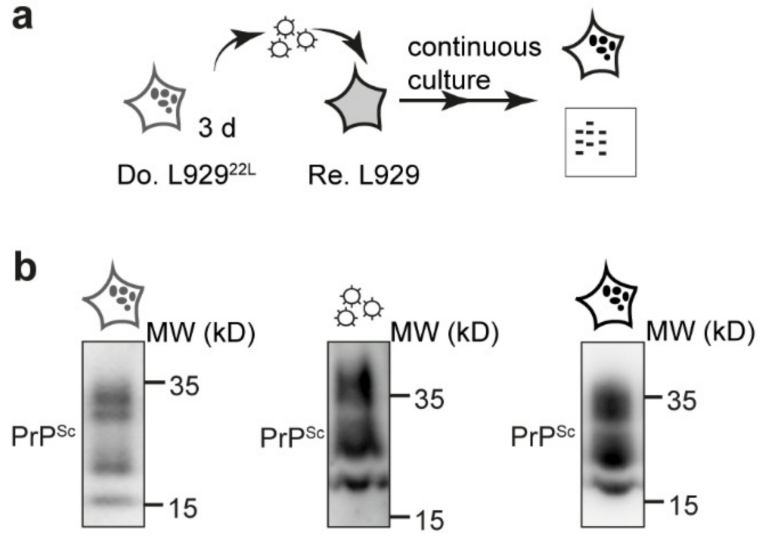

Figure 2. L929 cells infected with 22L secrete $\operatorname{Pr}^{\mathrm{Sc}}$ and prion infectivity in association with EVs. (a) EVs isolated from conditioned medium of L929 cells persistently infected with scrapie strain 22L (L92922L) were added to L929 cells. Recipient cells were passaged at least four times before $\mathrm{PrPSc}^{\mathrm{Sc}}$ formation was monitored by Western blot. (b) Western blot detection of $\mathrm{PrP}^{\mathrm{Sc}}$ in donor cells (L92922L) or $\mathrm{PrP}^{\mathrm{Sc}}$ in $\mathrm{EV}$ s derived from donor cells or $\mathrm{PrP}^{\mathrm{Sc}}$ in recipient cells after continuous culture. $\mathrm{PrPSc}^{\mathrm{Sc}}$ present in proteinase K-treated lysates was detected using anti-PrP antibody $4 \mathrm{H} 1$. $\mathrm{PrPSc}^{\mathrm{Sc}}$ runs as unglycosylated, monoglycosylated and diglycosylated bands.

Secretion of $\mathrm{PrP}^{\mathrm{Sc}}$ and/or prion infectivity into the cell culture supernatant has been reported for several (Table 2) but not all cell models [96]. The first demonstration that this infectivity is associated with extracellular vesicles (EVs) came from experiments with two different transgenic cell lines replicating sheep prions [118]. EVs are nano-sized vesicles that are secreted by virtually all cell types. EVs serve as communication devices that transfer different RNA types, lipids and proteins to distant acceptor cells [43]. EVs associated with prion infectivity exhibited the size and density of exosomes, vesicles derived by invagination of endosomal structures termed multivesicular bodies [118]. At least in RK13 cells, $90 \%$ of prion infectivity in conditioned medium could be recovered by $100,000 \times g$ ultracentrifugation, which sediments small EVs with densities corresponding to exosomes, but infectivity was also present in fractions containing larger vesicles and even in the non-pelletable fraction [13]. Prion infectivity is also associated with the $100,000 \times g$ fraction of conditioned medium from 22L-infected L929 cells (Figure 2). $\mathrm{PrP}^{\mathrm{Sc}}$ was also found associated with large EVs in another study, suggesting they were expelled from the cell surface [44]. Chemical and genetic manipulation of EV biogenesis in prion-infected cells also affects secretion of infectivity and subsequent infection of target cells $[75,119,120]$. Interestingly, in RK13 cells overexpressing ovine, mouse or vole $\operatorname{PrP}$ and infected with different prion strains, infectivity levels in EV fractions differed markedly [13]. Such differences in prion release could be due to general expression levels of $\operatorname{PrP}^{\mathrm{C}}$, cell clone differences or, more intriguingly, to differences in the sorting of prion strains through the 
endosomal pathway. As EVs preferentially bind to and exert their biological function in specific target cells $[65,121]$, it is quite possible that also the target cell tropism of EVs influences intercellular prion spreading. Further experiments with susceptible cells expressing wildtype levels of $\mathrm{PrP}^{\mathrm{C}}$ and infected with prions from the same species as well as different recipient cell lines will help to clarify these issues.

Table 2. Cell lines secreting prion infectivity.

\begin{tabular}{|c|c|c|c|c|c|c|c|c|}
\hline Cell Line & Origin & Prion Strain & $\begin{array}{l}\text { EV Isolation } \\
\text { Method }\end{array}$ & $\begin{array}{c}\text { PrPSc }^{\mathrm{Sc}} \\
\text { Association } \\
\text { with EV }\end{array}$ & $\begin{array}{c}\text { EM } \\
\text { Confirmation } \\
\text { EV }\end{array}$ & $\begin{array}{c}\text { Recipient } \\
\text { Cell }\end{array}$ & $\begin{array}{l}\text { Detection of } \\
\operatorname{PrP}^{S c} \text { p.i. }\end{array}$ & Reference \\
\hline GT1 & $\begin{array}{l}\text { Mouse } \\
\text { hypothalamic } \\
\text { neurons }\end{array}$ & RML & $\begin{array}{l}\text { Not isolated, } \\
\text { conditioned } \\
\text { medium } \\
\text { used }\end{array}$ & n.d. & No & $\begin{array}{l}\text { N2a } \\
\text { GT1 }\end{array}$ & 6-8 weeks & [57] \\
\hline \multirow[b]{2}{*}{ GT1-7 } & \multirow{2}{*}{$\begin{array}{l}\text { Mouse } \\
\text { hypothalamic } \\
\text { neurons }\end{array}$} & M1000 & $\begin{array}{l}\text { Differential } \\
\text { centrifuga- } \\
\text { tion }\end{array}$ & WB & No & $\begin{array}{c}\text { RK13 } \\
\text { expressing } \\
\text { murine PrP }\end{array}$ & 6 passages & [122] \\
\hline & & M1000 & $\begin{array}{l}\text { Differential } \\
\text { centrifuga- } \\
\text { tion }\end{array}$ & WB & Yes & $\begin{array}{l}\text { GT1-7; RK13 } \\
\text { expressing } \\
\text { murine PrP }\end{array}$ & One month & [77] \\
\hline NIH/3T3 & $\begin{array}{c}\text { Mouse } \\
\text { fibroblast+/- } \\
\text { infectionMuLV }\end{array}$ & $22 \mathrm{~L}$ & $\begin{array}{l}\text { Differential } \\
\text { centrifuga- } \\
\text { tion }\end{array}$ & WB & Yes & $\mathrm{NIH} / 3 \mathrm{~T} 3$ & $\begin{array}{l}16 \text { passages } \\
\text { Infection } \\
\text { only when } \\
\text { donors were } \\
\text { MuLV } \\
\text { infected }\end{array}$ & [22] \\
\hline \multirow{2}{*}{$\begin{array}{l}\text { RK13: } \\
\text { Rov }\end{array}$} & \multirow{2}{*}{$\begin{array}{l}\text { Rabbit kidney } \\
\text { epithelial cells } \\
\text { ectopically } \\
\text { expressing } \\
\text { ovine PrP }\end{array}$} & $\begin{array}{l}\text { Sheep } \\
\text { scrapie } \\
\text { PG127 }\end{array}$ & $\begin{array}{l}\text { Differential } \\
\text { centrifuga- } \\
\text { tion }\end{array}$ & WB & Yes & Rov & $\begin{array}{l}\text { Several } \\
\text { weeks }\end{array}$ & [118] \\
\hline & & $\begin{array}{l}\text { Sheep } \\
\text { scrapie } \\
\text { PG127 }\end{array}$ & $\begin{array}{l}\text { Differential } \\
\text { centrifuga- } \\
\text { tion }\end{array}$ & WB & No & Rov & 4 weeks & [13] \\
\hline \multirow{2}{*}{$\begin{array}{l}\text { RK13: } \\
\text { moRK13 }\end{array}$} & \multirow{2}{*}{$\begin{array}{l}\text { Rabbit kidney } \\
\text { epithelial cells } \\
\text { ectopically } \\
\text { expressing } \\
\text { murine PrP }\end{array}$} & $22 \mathrm{~L}$ & $\begin{array}{l}\text { Differential } \\
\text { centrifuga- } \\
\text { tion }\end{array}$ & WB & No & moRK13 & 4 weeks & [13] \\
\hline & & M1000 & $\begin{array}{l}\text { Differential } \\
\text { centrifuga- } \\
\text { tion }\end{array}$ & WB & Yes & $\begin{array}{l}\text { GT1-7; RK13 } \\
\text { expressing } \\
\text { murine PrP }\end{array}$ & One month & [77] \\
\hline \multirow[b]{2}{*}{$\mathrm{N} 2 \mathrm{a}$} & \multirow{2}{*}{$\begin{array}{c}\text { Mouse } \\
\text { neuroblastoma } \\
\text { expressing VSV-G } \\
\text { Mouse } \\
\text { neuroblastoma } \\
\text { overexpressing } \\
\text { murine PrP }\end{array}$} & $22 \mathrm{~L}$ & $\begin{array}{c}\text { Differential } \\
\text { centrifuga- } \\
\text { tion }\end{array}$ & n.d. & No & $\begin{array}{l}\text { L929 } \\
\text { CAD }\end{array}$ & $7-8$ passages & [72] \\
\hline & & $22 \mathrm{~L}$ & $\begin{array}{l}\text { Differential } \\
\text { centrifuga- } \\
\text { tion }\end{array}$ & WB & Yes & $\mathrm{N} 2 \mathrm{a}$ & 3 weeks & [75] \\
\hline Mov & $\begin{array}{c}\text { Immortalized } \\
\text { Schwann cell-like } \\
\text { cells from } \\
\text { transgenic mouse } \\
\text { expressing ovine } \\
\text { PrP }\end{array}$ & $\begin{array}{l}\text { Sheep } \\
\text { scrapie } \\
\text { PG127 }\end{array}$ & $\begin{array}{l}\text { Differential } \\
\text { centrifuga- } \\
\text { tion }\end{array}$ & WB & Yes & Mov & $\begin{array}{l}\text { Several } \\
\text { weeks }\end{array}$ & [118] \\
\hline $\begin{array}{l}\text { Hpl3-4 } \\
\text { moPrP- } \\
\text { 3F4 }\end{array}$ & $\begin{array}{c}\text { Mouse } \\
\text { hippocampus- } \\
\text { derived, } \\
\text { ectopically } \\
\text { expressing } \\
\text { epitope-tagged } \\
\text { mouse PrP }\end{array}$ & $22 \mathrm{~L}$ & $\begin{array}{l}\text { Not isolated, } \\
\text { conditioned } \\
\text { medium } \\
\text { used }\end{array}$ & n.d. & No & $\begin{array}{c}\text { Hpl3-4 } \\
\text { moPrP-3F4 }\end{array}$ & $\begin{array}{c}14-28 \\
\text { passages }\end{array}$ & [101] \\
\hline L929 & $\begin{array}{c}\text { Mouse } \\
\text { fibroblasts }\end{array}$ & $22 \mathrm{~L}$ & $\begin{array}{l}\text { Differential } \\
\text { centrifuga- } \\
\text { tion }\end{array}$ & WB & No & L929 & $\begin{array}{l}\text { Several } \\
\text { weeks }\end{array}$ & This study \\
\hline
\end{tabular}


Once released from their donor cells, EVs transmit cargo following interactions with specific receptors on their target cells. EVs can either directly fuse with the cell membrane, or they are taken up by endo- or macropinocytosis (reviewed in [73]). While EV cell tropism has been reported, only few receptor-ligand interactions mediating cell targeting have been identified. For example, uptake of some EVs is linked to integrin internalization [123]. Importantly, GAGs such as heparan sulfate proteoglycans, essential for prion propagation in cell culture [93,94], also mediate uptake of EVs [124]. The roles of proposed prion receptors Lrp1 or the $37 \mathrm{kDa} / 67 \mathrm{kDa}$ laminin receptor (LRP/LR) for prion loaded-EVs are unknown. As $\mathrm{PrPSc}^{\mathrm{Sc}}$ is exposed on the surface of the $\mathrm{EV}$, the association of the prion-loaded EVs with cell-surface or endosomal $\mathrm{PrP}^{\mathrm{C}}$ does not require escape from the endo-lysosomal system for initiation of $\mathrm{PrP}^{\mathrm{Sc}}$ formation. Exact cellular mechanisms of prion infection following EV uptake remain, however, unexplored.

\section{Role of Viruses in Intercellular Prion Spreading}

Growing evidence suggests that viruses or viral proteins have an impact on prion propagation.

A seminal study in mouse fibroblast cells demonstrated that secretion of prion infectivity was strongly enhanced when prion-infected fibroblast cultures were concomitantly infected with murine leukemia virus $\mathrm{MuLV}$ [22]. $\mathrm{PrPSc}^{\mathrm{Sc}}$ and $\mathrm{PrPC}^{\mathrm{C}}$ both co-localized with retroviral proteins Env and Gag at the cell membrane and were secreted in association with both retroviral particles and EVs. Viral infection strongly increased the release of $\operatorname{Pr} \mathrm{PSc}^{\mathrm{Sc}}$ and infectivity. The strong increase in $\mathrm{PrP}^{\mathrm{Sc}}$ secretion was attributed to the expression of the viral precursor protein Gag known to drive viral particle formation and enhance EV release. An increase in prion maintenance following retroviral Gag expression was also observed in an RK13 cell model propagating chronic wasting disease prions [51]. A possible explanation for the effect of retroviral Gag on prion secretion is that Gag proteins associated with prion-containing EVs promote their secretion, thereby increasing horizontal prion dissemination. However, downregulation of Gag expression in N2a cells did not affect the release of prion infectivity, arguing that prions were secreted independent of Gag [75]. We recently demonstrated that also viral glycoproteins can drastically increase intercellular transmission of prions and other protein aggregates [72]. Viral glycoproteins such as VSV-G of vesicular stomatitis virus or the spike S protein of SARS CoV-2 mediate receptor-specific target cell binding and subsequent merging of cell membranes or EVs with the cell surface or endosomes of recipient cells. Both VSV-G or spike S associated with the cell surface and EVs and enhanced protein aggregate transfer to recipient cells. Interestingly, viral glycoprotein VSV-G, but not spike S, also increased release of EVs. When prion-infected N2a cells were transfected with VSV-G plasmid, EVs from their conditioned medium strongly increased infection of L929 and CAD recipient cells. This was also the case when EVs from mock- or VSV-G-transfected donors were adjusted for comparable particle numbers. These results demonstrate that both elevated EV numbers and increased EV binding/fusion with the target cell membranes contribute to intercellular prion spreading.

That viruses might play a role in prion dissemination is also supported by findings in vivo. Small retroviruses have been implicated as cofactors that enhance the spread of scrapie by milk to suckling lambs through simultaneous infection of mammary glands with scrapie prions [63]. However, attempts to demonstrate the effect of MuLV retrovirus on prion propagation in mice failed, likely because target cells for virus and prions differ $[64,66]$. Surprisingly, a recent in vitro study demonstrated a very different mechanism of how viral infections could affect prion biogenesis. In a small percentage of surviving N2a cells infected with influenza virus, spontaneous $\mathrm{PrP}^{\mathrm{Sc}}$ formation was observed that was maintained upon continuous cell passage [125]. Mice injected with cell lysates succumbed to disease and exhibited full-blown prion pathogenesis. These experiments indicate that viral infections could in fact even trigger initial events leading to spontaneous formation of infectious prions. An important question to answer here is if spontaneous formation of prions is also observed within human cells expressing human $\mathrm{PrPC}^{\mathrm{C}}$. 


\section{Conclusions}

Concerted efforts in the last couple of years have provided us with long-awaited cellular models for propagation of bovine and human prions. However, despite important progress made in prion cell models, many unresolved questions remain, for example: we still do not understand which exact factors determine cellular prion permissiveness and why there are strain-specific differences in susceptibility even when the prion strains come from the same host. What is the exact intracellular site of $\mathrm{PrP}^{\mathrm{Sc}}$ formation? Additionally, what is the link between viral infection, prion biogenesis and dissemination? Results from cell culture models are exciting, as they demonstrate the strong effect of viral proteins on prion spreading.

Author Contributions: Conceptualization, I.M.V.; methodology, S.-E.H. and A.H.; data curation, S.-E.H., A.C.H. and A.S.H.; writing and editing, I.M.V., S.-E.H., A.C.H., A.S.H.; visualization, S.-E.H.; supervision, I.M.V. All authors have read and agreed to the published version of the manuscript.

Funding: This research received no external funding.

Institutional Review Board Statement: Not applicable.

Data Availability Statement: Data is contained within the article.

Conflicts of Interest: The authors declare no conflict of interest.

\section{References}

1. Gallardo, M.J.; Delgado, F.O. Animal prion diseases: A review of intraspecies transmission. Open Vet. J. 2021, 11, 707-723. [CrossRef] [PubMed]

2. Prusiner, S.B. Novel proteinaceous infectious particles cause scrapie. Science 1982, 216, 136-144. [CrossRef] [PubMed]

3. Oesch, B.; Westaway, D.; Walchli, M.; McKinley, M.P.; Kent, S.B.; Aebersold, R.; Barry, R.A.; Tempst, P.; Teplow, D.B.; Hood, L.E.; et al. A cellular gene encodes scrapie PrP 27-30 protein. Cell 1985, 40, 735-746. [CrossRef]

4. $\quad$ Bessen, R.A.; Kocisko, D.A.; Raymond, G.J.; Nandan, S.; Lansbury, P.T.; Caughey, B. Non-genetic propagation of strain-specific properties of scrapie prion protein. Nature 1995, 375, 698-700. [CrossRef] [PubMed]

5. Supattapone, S. Cofactor molecules: Essential partners for infectious prions. Prog. Mol. Biol. Transl. Sci. 2020, 175, 53-75. [CrossRef]

6. $\quad$ Burke, C.M.; Walsh, D.J.; Mark, K.M.K.; Deleault, N.R.; Nishina, K.A.; Agrimi, U.; Di Bari, M.A.; Supattapone, S. Cofactor and glycosylation preferences for in vitro prion conversion are predominantly determined by strain conformation. PLoS Pathog. 2020, 16, e1008495. [CrossRef]

7. Vella, L.J.; Greenwood, D.L.; Cappai, R.; Scheerlinck, J.P.; Hill, A.F. Enrichment of prion protein in exosomes derived from ovine cerebral spinal fluid. Vet. Immunol. Immunopathol. 2008, 124, 385-393. [CrossRef]

8. Sunyach, C.; Jen, A.; Deng, J.; Fitzgerald, K.T.; Frobert, Y.; Grassi, J.; McCaffrey, M.W.; Morris, R. The mechanism of internalization of glycosylphosphatidylinositol-anchored prion protein. EMBO J. 2003, 22, 3591-3601. [CrossRef]

9. Fehlinger, A.; Wolf, H.; Hossinger, A.; Duernberger, Y.; Pleschka, C.; Riemschoss, K.; Liu, S.; Bester, R.; Paulsen, L.; Priola, S.A.; et al. Prion strains depend on different endocytic routes for productive infection. Sci. Rep. 2017, 7, 6923. [CrossRef]

10. Pineau, H.; Sim, V.L. From Cell Culture to Organoids-Model Systems for Investigating Prion Strain Characteristics. Biomolecules 2021, 11, 106. [CrossRef]

11. Mouillet-Richard, S.; Nishida, N.; Pradines, E.; Laude, H.; Schneider, B.; Feraudet, C.; Grassi, J.; Launay, J.M.; Lehmann, S.; Kellermann, O. Prions impair bioaminergic functions through serotonin- or catecholamine-derived neurotoxins in neuronal cells. J. Biol. Chem. 2008, 283, 23782-23790. [CrossRef] [PubMed]

12. Tahir, W.; Abdulrahman, B.; Abdelaziz, D.H.; Thapa, S.; Walia, R.; Schatzl, H.M. An astrocyte cell line that differentially propagates murine prions. J. Biol. Chem. 2020, 295, 11572-11583. [CrossRef] [PubMed]

13. Marbiah, M.M.; Harvey, A.; West, B.T.; Louzolo, A.; Banerjee, P.; Alden, J.; Grigoriadis, A.; Hummerich, H.; Kan, H.M.; Cai, Y.; et al. Identification of a gene regulatory network associated with prion replication. EMBO J. 2014, 33, 1527-1547. [CrossRef] [PubMed]

14. Vorberg, I.M. All the Same? The Secret Life of Prion Strains within Their Target Cells. Viruses 2019, 11, 334. [CrossRef]

15. Marijanovic, Z.; Caputo, A.; Campana, V.; Zurzolo, C. Identification of an intracellular site of prion conversion. PLoS Pathog. 2009, 5, e1000426. [CrossRef]

16. Borchelt, D.R.; Scott, M.; Taraboulos, A.; Stahl, N.; Prusiner, S.B. Scrapie and cellular prion proteins differ in their kinetics of synthesis and topology in cultured cells. J. Cell Biol. 1990, 110, 743-752. [CrossRef]

17. Mattei, V.; Barenco, M.G.; Tasciotti, V.; Garofalo, T.; Longo, A.; Boller, K.; Lower, J.; Misasi, R.; Montrasio, F.; Sorice, M. Paracrine diffusion of $\operatorname{PrP}(\mathrm{C})$ and propagation of prion infectivity by plasma membrane-derived microvesicles. PLoS ONE 2009, 4, e5057. [CrossRef] 
18. Alais, S.; Simoes, S.; Baas, D.; Lehmann, S.; Raposo, G.; Darlix, J.L.; Leblanc, P. Mouse neuroblastoma cells release prion infectivity associated with exosomal vesicles. Biol. Cell 2008, 100, 603-615. [CrossRef]

19. Chesebro, B. Introduction to the transmissible spongiform encephalopathies or prion diseases. Br. Med. Bull. 2003, 66, 1-20. [CrossRef]

20. Pan, K.M.; Baldwin, M.; Nguyen, J.; Gasset, M.; Serban, A.; Groth, D.; Mehlhorn, I.; Huang, Z.; Fletterick, R.J.; Cohen, F.E.; et al. Conversion of alpha-helices into beta-sheets features in the formation of the scrapie prion proteins. Proc. Natl. Acad. Sci. USA 1993, 90, 10962-10966. [CrossRef]

21. Meisl, G.; Kurt, T.; Condado-Morales, I.; Bett, C.; Sorce, S.; Nuvolone, M.; Michaels, T.C.T.; Heinzer, D.; Avar, M.; Cohen, S.I.A.; et al Scaling analysis reveals the mechanism and rates of prion replication in vivo. Nat. Struct. Mol. Biol. 2021, 28, 365-372. [CrossRef] [PubMed]

22. Bruce, M.E. Scrapie strain variation and mutation. Br. Med. Bull. 1993, 49, 822-838. [CrossRef] [PubMed]

23. Bessen, R.A.; Marsh, R.F. Distinct PrP properties suggest the molecular basis of strain variation in transmissible mink encephalopathy. J. Virol. 1994, 68, 7859-7868. [CrossRef] [PubMed]

24. Safar, J.; Wille, H.; Itri, V.; Groth, D.; Serban, H.; Torchia, M.; Cohen Gousset, K.; Schiff, E.; Langevin, C.; Marijanovic, Z.; et al. Prions hijack tunnelling nanotubes for intercellular spread. Nat. Cell Biol. 2009, 11, 328-336. [CrossRef]

25. Safar, J.; Wille, H.; Itri, V.; Groth, D.; Serban, H.; Torchia, M.; Cohen, F.E.; Prusiner, S.B. Eight prion strains have PrP(Sc) molecules with different conformations. Nat. Med. 1998, 4, 1157-1165. [CrossRef]

26. Arellano-Anaya, Z.E.; Huor, A.; Leblanc, P.; Lehmann, S.; Provansal, M.; Raposo, G.; Andreoletti, O.; Vilette, D. Prion strains are differentially released through the exosomal pathway. Cell Mol. Life Sci. 2015, 72, 1185-1196. [CrossRef]

27. Kanu, N.; Imokawa, Y.; Drechsel, D.N.; Williamson, R.A.; Birkett, C.R.; Bostock, C.J.; Brockes, J.P. Transfer of scrapie prion infectivity by cell contact in culture. Curr. Biol. 2002, 12, 523-530. [CrossRef]

28. Grassmann, A.; Wolf, H.; Hofmann, J.; Graham, J.; Vorberg, I. Cellular aspects of prion replication in vitro. Viruses 2013, 5, 374-405. [CrossRef]

29. Castle, A.R.; Gill, A.C. Physiological Functions of the Cellular Prion Protein. Front. Mol Biosci. 2017, 4, 19. [CrossRef]

30. Panes, J.D.; Saavedra, P.; Pineda, B.; Escobar, K.; Cuevas, M.E.; Moraga-Cid, G.; Fuentealba, J.; Rivas, C.I.; Rezaei, H.; MunozMontesino, C. PrP (C) as a Transducer of Physiological and Pathological Signals. Front. Mol. Neurosci. 2021, $14,762918$. [CrossRef]

31. Go, G.; Yun, C.W.; Yoon, Y.M.; Lim, J.H.; Lee, J.H.; Lee, S.H. Role of $\operatorname{PrP(C)}$ in Cancer Stem Cell Characteristics and Drug Resistance in Colon Cancer Cells. Anticancer Res. 2020, 40, 5611-5620. [CrossRef] [PubMed]

32. Schmitt-Ulms, G.; Mehrabian, M.; Williams, D.; Ehsani, S. The IDIP framework for assessing protein function and its application to the prion protein. Biol. Rev. Camb. Philos. Soc. 2021, 96, 1907-1932. [CrossRef] [PubMed]

33. Taylor, D.R.; Hooper, N.M. The prion protein and lipid rafts. Mol. Membr. Biol. 2006, 23, 89-99. [CrossRef] [PubMed]

34. Leblanc, P.; Alais, S.; Porto-Carreiro, I.; Lehmann, S.; Grassi, J.; Raposo, G.; Darlix, J.L. Retrovirus infection strongly enhances scrapie infectivity release in cell culture. EMBO J. 2006, 25, 2674-2685. [CrossRef] [PubMed]

35. Altmeppen, H.C.; Prox, J.; Puig, B.; Dohler, F.; Falker, C.; Krasemann, S.; Glatzel, M. Roles of endoproteolytic alpha-cleavage and shedding of the prion protein in neurodegeneration. FEBS J. 2013, 280, 4338-4347. [CrossRef] [PubMed]

36. Shyng, S.L.; Moulder, K.L.; Lesko, A.; Harris, D.A. The N-terminal domain of a glycolipid-anchored prion protein is essential for its endocytosis via clathrin-coated pits. J. Biol. Chem. 1995, 270, 14793-14800. [CrossRef] [PubMed]

37. Vey, M.; Pilkuhn, S.; Wille, H.; Nixon, R.; DeArmond, S.J.; Smart, E.J.; Anderson, R.G.; Taraboulos, A.; Prusiner, S.B. Subcellular colocalization of the cellular and scrapie prion proteins in caveolae-like membranous domains. Proc. Natl. Acad. Sci. USA 1996, 93, 14945-14949. [CrossRef]

38. Uchiyama, K.; Tomita, M.; Yano, M.; Chida, J.; Hara, H.; Das, N.R.; Nykjaer, A.; Sakaguchi, S. Prions amplify through degradation of the VPS10P sorting receptor sortilin. PLoS Pathog. 2017, 13, e1006470. [CrossRef]

39. Taraboulos, A.; Rogers, M.; Borchelt, D.R.; McKinley, M.P.; Scott, M.; Serban, D.; Prusiner, S.B. Acquisition of protease resistance by prion proteins in scrapie-infected cells does not require asparagine-linked glycosylation. Proc. Natl. Acad. Sci. USA 1990, 87, 8262-8266. [CrossRef]

40. Heisler, F.F.; Pechmann, Y.; Wieser, I.; Altmeppen, H.C.; Veenendaal, L.; Muhia, M.; Schweizer, M.; Glatzel, M.; Krasemann, S.; Kneussel, M. Muskelin Coordinates $\operatorname{PrP}(\mathrm{C})$ Lysosome versus Exosome Targeting and Impacts Prion Disease Progression. Neuron 2018, 99, 1155-1169.e1159. [CrossRef]

41. Caughey, B.; Race, R.E.; Ernst, D.; Buchmeier, M.J.; Chesebro, B. Prion protein biosynthesis in scrapie-infected and uninfected neuroblastoma cells. J. Virol. 1989, 63, 175-181. [CrossRef] [PubMed]

42. Iwamaru, Y.; Takenouchi, T.; Ogihara, K.; Hoshino, M.; Takata, M.; Imamura, M.; Tagawa, Y.; Hayashi-Kato, H.; Ushiki-Kaku, Y.; Shimizu, Y.; et al. Microglial cell line established from prion protein-overexpressing mice is susceptible to various murine prion strains. J. Virol. 2007, 81, 1524-1527. [CrossRef] [PubMed]

43. Caughey, B.; Raymond, G.J. The scrapie-associated form of PrP is made from a cell surface precursor that is both protease- and phospholipase-sensitive. J. Biol. Chem. 1991, 266, 18217-18223. [CrossRef]

44. Caughey, B.; Baron, G.S.; Chesebro, B.; Jeffrey, M. Getting a grip on prions: Oligomers, amyloids, and pathological membrane interactions. Annu. Rev. Biochem. 2009, 78, 177-204. [CrossRef] 
45. Hutti, C.R.; Welle, K.A.; Hryhorenko, J.R.; Ghaemmaghami, S. Publisher Correction: Global analysis of protein degradation in prion infected cells. Sci. Rep. 2020, 10, 12952. [CrossRef]

46. Prusiner, S.B. The prion diseases. Brain Pathol. 1998, 8, 499-513. [CrossRef]

47. Klohn, P.C.; Stoltze, L.; Flechsig, E.; Enari, M.; Weissmann, C. A quantitative, highly sensitive cell-based infectivity assay for mouse scrapie prions. Proc. Natl. Acad. Sci. USA 2003, 100, 11666-11671. [CrossRef]

48. Nishida, N.; Harris, D.A.; Vilette, D.; Laude, H.; Frobert, Y.; Grassi, J.; Casanova, D.; Milhavet, O.; Lehmann, S. Successful transmission of three mouse-adapted scrapie strains to murine neuroblastoma cell lines overexpressing wild-type mouse prion protein. J. Virol. 2000, 74, 320-325. [CrossRef]

49. Sarnataro, D.; Caputo, A.; Casanova, P.; Puri, C.; Paladino, S.; Tivodar, S.S.; Campana, V.; Tacchetti, C.; Zurzolo, C. Lipid rafts and clathrin cooperate in the internalization of PrP in epithelial FRT cells. PLoS ONE 2009, 4, e5829. [CrossRef]

50. Schatzl, H.M.; Laszlo, L.; Holtzman, D.M.; Tatzelt, J.; DeArmond, S.J.; Weiner, R.I.; Mobley, W.C.; Prusiner, S.B. A hypothalamic neuronal cell line persistently infected with scrapie prions exhibits apoptosis. J. Virol. 1997, 71, 8821-8831. [CrossRef]

51. Fevrier, B.; Vilette, D.; Archer, F.; Loew, D.; Faigle, W.; Vidal, M.; Laude, H.; Raposo, G. Cells release prions in association with exosomes. Proc. Natl. Acad. Sci. USA 2004, 101, 9683-9688. [CrossRef] [PubMed]

52. Yanez-Mo, M.; Siljander, P.R.; Andreu, Z.; Zavec, A.B.; Borras, F.E.; Buzas, E.I.; Buzas, K.; Casal, E.; Cappello, F.; Carvalho, J.; et al Biological properties of extracellular vesicles and their physiological functions. J. Extracell. Vesicles 2015, 4, 27066. [CrossRef] [PubMed]

53. Race, R.E.; Fadness, L.H.; Chesebro, B. Characterization of scrapie infection in mouse neuroblastoma cells. J. Gen. Virol. 1987, 68, 1391-1399. [CrossRef] [PubMed]

54. Cronier, S.; Laude, H.; Peyrin, J.M. Prions can infect primary cultured neurons and astrocytes and promote neuronal cell death. Proc. Natl. Acad. Sci. USA 2004, 101, 12271-12276. [CrossRef] [PubMed]

55. Archer, F.; Bachelin, C.; Andreoletti, O.; Besnard, N.; Perrot, G.; Langevin, C.; Le Dur, A.; Vilette, D.; Baron-Van Evercooren, A.; Vilotte, J.L.; et al. Cultured peripheral neuroglial cells are highly permissive to sheep prion infection. J. Virol. 2004, 78, 482-490. [CrossRef]

56. Vilette, D.; Andreoletti, O.; Archer, F.; Madelaine, M.F.; Vilotte, J.L.; Lehmann, S.; Laude, H. Ex vivo propagation of infectious sheep scrapie agent in heterologous epithelial cells expressing ovine prion protein. Proc. Natl. Acad. Sci. USA 2001, 98, 4055-4059. [CrossRef]

57. Miyazawa, K.; Masujin, K.; Okada, H.; Ushiki-Kaku, Y.; Matsuura, Y.; Yokoyama, T. Selective propagation of mouse-passaged scrapie prions with long incubation period from a mixed prion population using GT1-7 cells. PLoS ONE 2017, 12, e0179317. [CrossRef]

58. Walia, R.; Ho, C.C.; Lee, C.; Gilch, S.; Schatzl, H.M. Gene-edited murine cell lines for propagation of chronic wasting disease prions. Sci. Rep. 2019, 9, 11151. [CrossRef]

59. Raymond, G.J.; Olsen, E.A.; Lee, K.S.; Raymond, L.D.; Bryant, P.K., 3rd; Baron, G.S.; Caughey, W.S.; Kocisko, D.A.; McHolland, L.E.; Favara, C.; et al. Inhibition of protease-resistant prion protein formation in a transformed deer cell line infected with chronic wasting disease. J. Virol. 2006, 80, 596-604. [CrossRef]

60. Bian, J.; Napier, D.; Khaychuck, V.; Angers, R.; Graham, C.; Telling, G. Cell-based quantification of chronic wasting disease prions J. Virol. 2010, 84, 8322-8326. [CrossRef]

61. Hannaoui, S.; Gougerot, A.; Privat, N.; Levavasseur, E.; Bizat, N.; Hauw, J.J.; Brandel, J.P.; Haik, S. Cycline efficacy on the propagation of human prions in primary cultured neurons is strain-specific. J. Infect. Dis. 2014, 209, 1144-1148. [CrossRef] [PubMed]

62. Mahal, S.P.; Baker, C.A.; Demczyk, C.A.; Smith, E.W.; Julius, C.; Weissmann, C. Prion strain discrimination in cell culture: The cell panel assay. Proc. Natl. Acad. Sci. USA 2007, 104, 20908-20913. [CrossRef] [PubMed]

63. Mathieu, M.; Martin-Jaular, L.; Lavieu, G.; Thery, C. Specificities of secretion and uptake of exosomes and other extracellular vesicles for cell-to-cell communication. Nat. Cell Biol. 2019, 21, 9-17. [CrossRef] [PubMed]

64. Kalluri, R.; LeBleu, V.S. The biology, function, and biomedical applications of exosomes. Science 2020, 367, eaau6977. [CrossRef] [PubMed]

65. Marzo, L.; Marijanovic, Z.; Browman, D.; Chamoun, Z.; Caputo, A.; Zurzolo, C. 4-hydroxytamoxifen leads to PrPSc clearance by conveying both PrPC and PrPSc to lysosomes independently of autophagy. J. Cell Sci. 2013, 126, 1345-1354. [CrossRef]

66. Fuentes, P.; Sese, M.; Guijarro, P.J.; Emperador, M.; Sanchez-Redondo, S.; Peinado, H.; Hummer, S.; Ramon, Y.C.S. ITGB3-mediated uptake of small extracellular vesicles facilitates intercellular communication in breast cancer cells. Nat. Commun. 2020, $11,4261$. [CrossRef]

67. Christianson, H.C.; Svensson, K.J.; van Kuppevelt, T.H.; Li, J.P.; Belting, M. Cancer cell exosomes depend on cell-surface heparan sulfate proteoglycans for their internalization and functional activity. Proc. Natl. Acad. Sci. USA 2013, 110, 17380-17385. [CrossRef]

68. Ligios, C.; Sigurdson, C.J.; Santucciu, C.; Carcassola, G.; Manco, G.; Basagni, M.; Maestrale, C.; Cancedda, M.G.; Madau, L.; Aguzzi, A. PrPSc in mammary glands of sheep affected by scrapie and mastitis. Nat. Med. 2005, 11, 1137-1138. [CrossRef]

69. Vorberg, I.; Raines, A.; Story, B.; Priola, S.A. Susceptibility of common fibroblast cell lines to transmissible spongiform encephalopathy agents. J. Infect. Dis. 2004, 189, 431-439. [CrossRef]

70. Hara, H.; Chida, J.; Uchiyama, K.; Pasiana, A.D.; Takahashi, E.; Kido, H.; Sakaguchi, S. Neurotropic influenza A virus infection causes prion protein misfolding into infectious prions in neuroblastoma cells. Sci. Rep. 2021, 11, 10109. [CrossRef] 
71. Birkett, C.R.; Hennion, R.M.; Bembridge, D.A.; Clarke, M.C.; Chree, A.; Bruce, M.E.; Bostock, C.J. Scrapie strains maintain biological phenotypes on propagation in a cell line in culture. EMBO J. 2001, 20, 3351-3358. [CrossRef]

72. Casaccia-Bonnefil, P.; Kascsak, R.J.; Fersko, R.; Callahan, S.; Carp, R.I. Brain regional distribution of prion protein PrP27-30 in mice stereotaxically microinjected with different strains of scrapie. J. Infect. Dis. 1993, 167, 7-12. [CrossRef] [PubMed]

73. Gerdes, H.H.; Carvalho, R.N. Intercellular transfer mediated by tunneling nanotubes. Curr. Opin. Cell Biol. 2008, $20,470-475$. [CrossRef]

74. Magalhaes, A.C.; Baron, G.S.; Lee, K.S.; Steele-Mortimer, O.; Dorward, D.; Prado, M.A.; Caughey, B. Uptake and neuritic transport of scrapie prion protein coincident with infection of neuronal cells. J. Neurosci. 2005, 25, 5207-5216. [CrossRef] [PubMed]

75. Marshall, K.E.; Hughson, A.; Vascellari, S.; Priola, S.A.; Sakudo, A.; Onodera, T.; Baron, G.S. PrP Knockout Cells Expressing Transmembrane PrP Resist Prion Infection. J. Virol. 2017, 91, e01686-e01716. [CrossRef] [PubMed]

76. Chivet, M.; Javalet, C.; Laulagnier, K.; Blot, B.; Hemming, F.J; Sadoul, R. Exosomes secreted by cortical neurons upon glutamatergic synapse activation specifically interact with neurons. J. Extracell Vesicles 2014, 3, 24722. [CrossRef]

77. Leblanc, P.; Hasenkrug, K.; Ward, A.; Myers, L.; Messer, R.J.; Alais, S.; Timmes, A.; Priola, S.A. Co-infection with the friend retrovirus and mouse scrapie does not alter prion disease pathogenesis in susceptible mice. PLoS ONE 2012, 7, e30872. [CrossRef]

78. Butler, D.A.; Scott, M.R.; Bockman, J.M.; Borchelt, D.R.; Taraboulos, A.; Hsiao, K.K.; Kingsbury, D.T.; Prusiner, S.B. Scrapie-infected murine neuroblastoma cells produce protease-resistant prion proteins. J. Virol. 1988, 62, 1558-1564. [CrossRef]

79. Rubenstein, R.; Carp, R.I.; Callahan, S.M. In vitro replication of scrapie agent in a neuronal model: Infection of PC12 cells. J. Gen. Virol. 1984, 65, 2191-2198. [CrossRef]

80. Hannaoui, S.; Maatouk, L.; Privat, N.; Levavasseur, E.; Faucheux, B.A.; Haik, S. Prion propagation and toxicity occur in vitro with two-phase kinetics specific to strain and neuronal type. J. Virol. 2013, 87, 2535-2548. [CrossRef]

81. Clarke, M.C.; Haig, D.A. Multiplication of scrapie agent in cell culture. Res. Vet. Sci. 1970, 11, 500-501. [CrossRef]

82. Roffe, M.; Beraldo, F.H.; Bester, R.; Nunziante, M.; Bach, C.; Mancini, G.; Gilch, S.; Vorberg, I.; Castilho, B.A.; Martins, V.R.; et al. Prion protein interaction with stress-inducible protein 1 enhances neuronal protein synthesis via mTOR. Proc. Natl. Acad. Sci. USA 2010, 107, 13147-13152. [CrossRef] [PubMed]

83. Jen, A.; Parkyn, C.J.; Mootoosamy, R.C.; Ford, M.J.; Warley, A.; Liu, Q.; Bu, G.; Baskakov, I.V.; Moestrup, S.; McGuinness, L.; et al. Neuronal low-density lipoprotein receptor-related protein 1 binds and endocytoses prion fibrils via receptor cluster 4 . J. Cell Sci. 2010, 123, 246-255. [CrossRef] [PubMed]

84. Coleman, B.M.; Hanssen, E.; Lawson, V.A.; Hill, A.F. Prion-infected cells regulate the release of exosomes with distinct ultrastructural features. FASEB J. 2012, 26, 4160-4173. [CrossRef] [PubMed]

85. Liu, S.; Hossinger, A.; Heumuller, S.E.; Hornberger, A.; Buravlova, O.; Konstantoulea, K.; Muller, S.A.; Paulsen, L.; Rousseau, F.; Schymkowitz, J.; et al. Highly efficient intercellular spreading of protein misfolding mediated by viral ligand-receptor interactions. Nat. Commun. 2021, 12, 5739. [CrossRef]

86. Bourkas, M.E.C.; Arshad, H.; Al-Azzawi, Z.A.M.; Halgas, O.; Shikiya, R.A.; Mehrabian, M.; Schmitt-Ulms, G.; Bartz, J.C.; Watts, J.C. Engineering a murine cell line for the stable propagation of hamster prions. J. Biol. Chem. 2019, 294, 4911-4923. [CrossRef]

87. Courageot, M.P.; Daude, N.; Nonno, R.; Paquet, S.; Di Bari, M.A.; Le Dur, A.; Chapuis, J.; Hill, A.F.; Agrimi, U.; Laude, H.; et al. A cell line infectible by prion strains from different species. J Gen Virol 2008, 89, 341-347. [CrossRef]

88. Guo, B.B.; Bellingham, S.A.; Hill, A.F. Stimulating the Release of Exosomes Increases the Intercellular Transfer of Prions. J. Biol. Chem. 2016, 291, 5128-5137. [CrossRef]

89. Hasebe, R.; Tanaka, M.; Suzuki, A.; Yamasaki, T.; Horiuchi, M. Complement factors alter the amount of PrP(Sc) in primary-cultured mouse cortical neurons associated with increased membrane permeability. Virology 2016, 496, 9-20. [CrossRef]

90. Krejciova, Z.; Alibhai, J.; Zhao, C.; Krencik, R.; Rzechorzek, N.M.; Ullian, E.M.; Manson, J.; Ironside, J.W.; Head, M.W.; Chandran, S. Human stem cell-derived astrocytes replicate human prions in a PRNP genotype-dependent manner. J. Exp. Med. 2017, 214, 3481-3495. [CrossRef]

91. Follet, J.; Lemaire-Vieille, C.; Blanquet-Grossard, F.; Podevin-Dimster, V.; Lehmann, S.; Chauvin, J.P.; Decavel, J.P.; Varea, R.; Grassi, J.; Fontes, M.; et al. PrP expression and replication by Schwann cells: Implications in prion spreading. J. Virol. 2002 76, 2434-2439. [CrossRef] [PubMed]

92. Cronier, S.; Beringue, V.; Bellon, A.; Peyrin, J.M.; Laude, H. Prion strain- and species-dependent effects of antiprion molecules in primary neuronal cultures. J. Virol. 2007, 81, 13794-13800. [CrossRef] [PubMed]

93. Vella, L.J.; Sharples, R.A.; Lawson, V.A.; Masters, C.L.; Cappai, R.; Hill, A.F. Packaging of prions into exosomes is associated with a novel pathway of PrP processing. J. Pathol. 2007, 211, 582-590. [CrossRef] [PubMed]

94. Nishida, N.; Katamine, S.; Manuelidis, L. Reciprocal interference between specific CJD and scrapie agents in neural cell cultures. Science 2005, 310, 493-496. [CrossRef] [PubMed]

95. Arjona, A.; Simarro, L.; Islinger, F.; Nishida, N.; Manuelidis, L. Two Creutzfeldt-Jakob disease agents reproduce prion proteinindependent identities in cell cultures. Proc. Natl. Acad. Sci. USA 2004, 101, 8768-8773. [CrossRef]

96. Dinkel, K.D.; Schneider, D.A.; Munoz-Gutierrez, J.F.; McElliott, V.R.; Stanton, J.B. Correlation of cellular factors and differential scrapie prion permissiveness in ovine microglia. Virus Res. 2017, 240, 69-80. [CrossRef]

97. Brown, C.A.; Schmidt, C.; Poulter, M.; Hummerich, H.; Klohn, P.C.; Jat, P.; Mead, S.; Collinge, J.; Lloyd, S.E. In vitro screen of prion disease susceptibility genes using the scrapie cell assay. Hum. Mol. Genet. 2014, 23, 5102-5108. [CrossRef]

98. Bosque, P.J.; Prusiner, S.B. Cultured cell sublines highly susceptible to prion infection. J. Virol. 2000, 74, 4377-4386. [CrossRef] 
99. Philiastides, A.; Ribes, J.M.; Yip, D.C.; Schmidt, C.; Benilova, I.; Klohn, P.C. A New Cell Model for Investigating Prion Strain Selection and Adaptation. Viruses 2019, 11, 888. [CrossRef]

100. Kim, H.J.; Tark, D.S.; Lee, Y.H.; Kim, M.J.; Lee, W.Y.; Cho, I.S.; Sohn, H.J.; Yokoyama, T. Establishment of a cell line persistently infected with chronic wasting disease prions. J. Vet. Med. Sci. 2012, 74, 1377-1380. [CrossRef]

101. Lawson, V.A.; Vella, L.J.; Stewart, J.D.; Sharples, R.A.; Klemm, H.; Machalek, D.M.; Masters, C.L.; Cappai, R.; Collins, S.J.; Hill, A.F. Mouse-adapted sporadic human Creutzfeldt-Jakob disease prions propagate in cell culture. Int. J. Biochem. Cell Biol. 2008, 40, 2793-2801. [CrossRef] [PubMed]

102. Tark, D.; Kim, H.; Neale, M.H.; Kim, M.; Sohn, H.; Lee, Y.; Cho, I.; Joo, Y.; Windl, O. Generation of a persistently infected MDBK cell line with natural bovine spongiform encephalopathy (BSE). PLoS ONE 2015, 10, e0115939. [CrossRef] [PubMed]

103. Baron, G.S.; Magalhaes, A.C.; Prado, M.A.; Caughey, B. Mouse-adapted scrapie infection of SN56 cells: Greater efficiency with microsome-associated versus purified PrP-res. J. Virol. 2006, 80, 2106-2117. [CrossRef] [PubMed]

104. Greil, C.S.; Vorberg, I.M.; Ward, A.E.; Meade-White, K.D.; Harris, D.A.; Priola, S.A. Acute cellular uptake of abnormal prion protein is cell type and scrapie-strain independent. Virology 2008, 379, 284-293. [CrossRef] [PubMed]

105. Michiels, E.; Liu, S.; Gallardo, R.; Louros, N.; Mathelie-Guinlet, M.; Dufrene, Y.; Schymkowitz, J.; Vorberg, I.; Rousseau, F. Entropic Bristles Tune the Seeding Efficiency of Prion-Nucleating Fragments. Cell Rep. 2020, 30, 2834-2845 e2833. [CrossRef]

106. Walzlein, J.H.; Schwenke, K.A.; Beekes, M. Propagation of CJD Prions in Primary Murine Glia Cells Expressing Human PrP(c). Pathogens 2021, 10, 1060. [CrossRef]

107. Properzi, F.; Badhan, A.; Klier, S.; Schmidt, C.; Klohn, P.C.; Wadsworth, J.D.; Clarke, A.R.; Jackson, G.S.; Collinge, J. Physical, chemical and kinetic factors affecting prion infectivity. Prion 2016, 10, 251-261. [CrossRef]

108. Horonchik, L.; Tzaban, S.; Ben-Zaken, O.; Yedidia, Y.; Rouvinski, A.; Papy-Garcia, D.; Barritault, D.; Vlodavsky, I.; Taraboulos, A Heparan sulfate is a cellular receptor for purified infectious prions. J. Biol. Chem. 2005, 280, 17062-17067. [CrossRef]

109. Wolf, H.; Grassmann, A.; Bester, R.; Hossinger, A.; Mohl, C.; Paulsen, L.; Groschup, M.H.; Schatzl, H.; Vorberg, I. Modulation of Glycosaminoglycans Affects PrPSc Metabolism but Does Not Block PrPSc Uptake. J. Virol. 2015, 89, 9853-9864. [CrossRef]

110. Leucht, C.; Simoneau, S.; Rey, C.; Vana, K.; Rieger, R.; Lasmezas, C.I.; Weiss, S. The 37 kDa/67 kDa laminin receptor is required for $\operatorname{PrP}(\mathrm{Sc})$ propagation in scrapie-infected neuronal cells. EMBO Rep. 2003, 4, 290-295. [CrossRef]

111. Victoria, G.S.; Arkhipenko, A.; Zhu, S.; Syan, S.; Zurzolo, C. Astrocyte-to-neuron intercellular prion transfer is mediated by cell-cell contact. Sci. Rep. 2016, 6, 20762. [CrossRef] [PubMed]

112. Yamasaki, T.; Baron, G.S.; Suzuki, A.; Hasebe, R.; Horiuchi, M. Characterization of intracellular dynamics of inoculated PrP-res and newly generated $\operatorname{PrP}(\mathrm{Sc})$ during early stage prion infection in Neuro2a cells. Virology 2014, 450-451, 324-335. [CrossRef] [PubMed]

113. Vorberg, I.; Raines, A.; Priola, S.A. Acute formation of protease-resistant prion protein does not always lead to persistent scrapie infection in vitro. J. Biol. Chem. 2004, 279, 29218-29225. [CrossRef] [PubMed]

114. Ghaemmaghami, S.; Phuan, P.W.; Perkins, B.; Ullman, J.; May, B.C.; Cohen, F.E.; Prusiner, S.B. Cell division modulates prion accumulation in cultured cells. Proc. Natl. Acad. Sci. USA 2007, 104, 17971-17976. [CrossRef] [PubMed]

115. Krauss, S.; Vorberg, I. Prions Ex Vivo: What Cell Culture Models Tell Us about Infectious Proteins. Int. J. Cell. Biol. 2013, 2013, 704546. [CrossRef] [PubMed]

116. Maas, E.; Geissen, M.; Groschup, M.H.; Rost, R.; Onodera, T.; Schatzl, H.; Vorberg, I.M. Scrapie infection of prion protein-deficient cell line upon ectopic expression of mutant prion proteins. J. Biol. Chem. 2007, 282, 18702-18710. [CrossRef] [PubMed]

117. Bach, C.; Gilch, S.; Rost, R.; Greenwood, A.D.; Horsch, M.; Hajj, G.N.; Brodesser, S.; Facius, A.; Schadler, S.; Sandhoff, K.; et al Prion-induced activation of cholesterogenic gene expression by Srebp2 in neuronal cells. J. Biol. Chem. 2009, 284, 31260-31269. [CrossRef]

118. Borchelt, D.R.; Taraboulos, A.; Prusiner, S.B. Evidence for synthesis of scrapie prion proteins in the endocytic pathway. J. Biol. Chem. 1992, 267, 16188-16199. [CrossRef]

119. McNally, K.L.; Ward, A.E.; Priola, S.A. Cells expressing anchorless prion protein are resistant to scrapie infection. J. Virol. 2009, 83, 4469-4475. [CrossRef]

120. Rouvinski, A.; Karniely, S.; Kounin, M.; Moussa, S.; Goldberg, M.D.; Warburg, G.; Lyakhovetsky, R.; Papy-Garcia, D.; Kutzsche, J.; Korth, C.; et al. Live imaging of prions reveals nascent PrPSc in cell-surface, raft-associated amyloid strings and webs. J. Cell Biol. 2014, 204, 423-441. [CrossRef]

121. Yim, Y.I.; Park, B.C.; Yadavalli, R.; Zhao, X.; Eisenberg, E.; Greene, L.E. The multivesicular body is the major internal site of prion conversion. J. Cell Sci. 2015, 128, 1434-1443. [CrossRef] [PubMed]

122. Chernoff, Y.O.; Lindquist, S.L.; Ono, B.; Inge-Vechtomov, S.G.; Liebman, S.W. Role of the chaperone protein Hsp104 in propagation of the yeast prion-like factor [psi+]. Science 1995, 268, 880-884. [CrossRef]

123. Zhu, S.; Victoria, G.S.; Marzo, L.; Ghosh, R.; Zurzolo, C. Prion aggregates transfer through tunneling nanotubes in endocytic vesicles. Prion 2015, 9, 125-135. [CrossRef] [PubMed] 
124. Vilette, D.; Laulagnier, K.; Huor, A.; Alais, S.; Simoes, S.; Maryse, R.; Provansal, M.; Lehmann, S.; Andreoletti, O.; Schaeffer, L.; et al. Efficient inhibition of infectious prions multiplication and release by targeting the exosomal pathway. Cell Mol. Life Sci. 2015, 72, 4409-4427. [CrossRef] [PubMed]

125. Krasemann, S.; Neumann, M.; Luepke, J.P.; Grashorn, J.; Wurr, S.; Stocking, C.; Glatzel, M. Persistent retroviral infection with MoMuLV influences neuropathological signature and phenotype of prion disease. Acta Neuropathol. 2012, 124, 111-126. [CrossRef] [PubMed] 